\title{
Deviation from Optimal Level of Cash Holdings and Cumulative Abnormal Returns
}

\author{
Mir Askari Akbari ${ }^{1}$, Samira Rahmani ${ }^{2}$, Reza Ahmadi $^{3}$, Hooman Shababi ${ }^{3, *}$ \\ ${ }^{1}$ Department of Accounting, Islamic Azad University, Babol Branch, Babol, Iran \\ ${ }^{2}$ Department of Management and Accounting, Qazvin Islamic Azad University (QIAU) \\ ${ }^{3}$ Faculty member at Rahedanesh Institute of Higher Education, Babol, Iran \\ *Corresponding Author: Hooman-shababi@rahedanesh.ac.ir
}

Copyright (C) 2014 Horizon Research Publishing All rights reserved.

\begin{abstract}
The Present study investigates the relationship between deviation from optimal level of cash holdings and future performance in 188 active accepted firms of Tehran Stock Exchange (TSE) during 2003-2012. To do so, Opler et al. model was extended to determine optimal cash level and positive and negative deviation from optimal level of cash holding are applied as excess and sufficient cash. Also regression model with panel data is used to investigate the relationship between cash holdings and future performance. Furthermore, cumulative abnormal returns (CAR) variable is used as future performance indices. The results indicate that there is a negative and significant relationship between deviation from optimal level of cash holdings and future performance. It shows that companies which hold more or less cash than optimal cash will have lower investment returns.
\end{abstract}

Keywords Optimal Level of Cash holding, Future Performance, Panel Data, Cumulative Abnormal Returns

JEL Classification: C33, G14, M41

\section{Introduction}

Cash resources are critical to any economic units, which can allocate substantial part of its assets. Cash provides liquidity, which is vital to business operations. Balance creating between available cash and cash needs is one of the most important factors in economic health of companies and their activities. Generally, managers are seeking for an optimal level of cash holdings, respecting to pros and cons of cash holdings. Cash should be held in the level which trades off between excess and insufficient cash holding costs. In other words, firms are followed by a level of liquidity which due to lack of liquidity, does not lead them to increase in liquidity risk and the cost of external financing and also, with holdings excess cash does not miss investment opportunities. Therefore, the proper and efficient management of liquidity increases efficiency and thereby improve corporate future performance. If cash level has the predicting power of future performance so any deviation may reflect in current and future returns.

Mikkelson and Partch (2003), Simutin (2010) and Anagnostopoulou (2012) show in their studies, firms which hold excess cash have better performance. They believe that holding excess cash does not have negative effect on firm performance and on the contrary, improves their future performance. In contrast, Dittmar and Mahart (2007) and Harford et al (2008) find evidence that the increase in cash decrease the future returns on assets. Needing cash is a basic requirement for every company. Companies with insufficient or excess cash will be faced with many problems; therefore, cash management needs to make the best decision for the use of cash or cash resources of each company. Cash is the most liquid and best of company assets and if the company is well managed, the company will make a great success, although if not properly planned and managed, may lead the company to bankruptcy (U.S. Treasury, 2002).

Cash management is a factor that has a positive impact on firm performance. Company optimal level of cash, according to the specific characteristics of the company, can be a great help to managers to increase performance level and appropriate use of resources. The cash held more (excess cash) or less (insufficient cash) than the optimal level, include opportunity costs and the cost of external financing and has a negative effect on the overall performance of the companies and their future returns. Investigation on the relationship between corporate cash holdings and future performance is important and can be very useful in the evaluation of companies by managers, investors and other beneficiaries. Although few studies have investigated the relationship between the cash and firms future performance with insufficient cash so far, the present study examines whether there is a relationship between excess or insufficient cash with future performance. With assuming the existence of an optimal level of cash, any deviation from that cause costs to companies which will impact negatively the company's future performance. 
Furthermore, as a robustness check, the study takes into consideration the dynamic behavior by adopting the Generalized Method of Moments (GMM). The results are consistent with the static approach. The remainder of the paper is organized as follows. Section 2 we discuss the insights we draw from prior research in motivating our investigation and Section 3 presents hypothesis development; in Section 4, the methodology is discussed, in Section 5, presents data and summary statistics and Section 6 presents the results of the regression models. Finally, Section 7 concludes.

\section{Literature Review}

Today, the company's decision to determine the level of cash holdings is a subject that has attracted the attention of many researchers. It can be expected that strategic decisions about how to manage cash from the investor's perspective is important.

Mikkelson and Partch (2003) investigate firms that consistently hold a high cash balance from 1986 to 1991, and find that there is no significant relationship between excess cash and operating performance. However, their data requirements restrict their sample size to 89 firms, making it difficult to extrapolate from their results. Their results indicate that future performance is significantly lower in excess cash level, but because their focus is on governance and cash holdings, their sample is restricted to only those firms with governance data available.

Kevin (2007) examines the relation between expected cash holdings, future performance and stock return. In his research, he follows Opler et al. (1999) model and presents a more comprehensive model of the expected cash holdings and provides strong evidence in support of the statistical models of transaction cash holdings. His main findings include: (1) the deviation is higher, lower future returns on assets; (2) the mentioned relation observes in both positive and negative deviations; negative deviations of future returns on assets is stronger than positive ones; (3) the ultimate effect on future returns on assets increases by increasing the deviation; (4) when the company deviates from the expected cash, future performance is worse in all areas. His results also show that the deviation from the expected cash influences future stock returns.

Oler and Picconi (2007) investigate the impact of insufficient cash holdings on future performance with analyzing of 17 years financial data from 1989 to 2005 . They argue that the cumulative abnormal returns and the future operating performance of the company can be predicted based on deviation from estimated optimal level of cash holdings. Their findings indicate that cash balances lower than optimal level is strongly associated with operating performance in future. And as well as future operating performance reduces while companies hold more cash.

The experimental results presented by Palazzo (2009) shows that the three-factor Fama and French variables are not able to explain properly the difference between the average returns in firms. In this research, the author uses another criterion to investigate the return difference in portfolios with high and low (HCMLC) 1 level of liquidity. In this study it is assumed that companies in financing their investment are able use two approaches of capital release and retained earnings. Capital release includes cash costs such as the legal representation right and bankers brokerage. Saving cash allow companies to avoid costly external financing, but the obtained return is less than what shareholders expect. Due to inclusion of the high risk cash flow, precautionary motivation is a key element to explain the positive relationship between corporate cash holdings and investment average return.

Simutin (2010) argues that among firms with excess cash, those companies that have surplus cash than other firms, have $4 \%$ monthly higher returns. Also companies that have more liquid assets, have higher future investment and market beta. Stock of companies which hold excess cash have worse performance rather than firms which hold lower levels of cash. The author indicates that despite liquidity risk is lower compared to other assets, companies that have high level of cash, have higher market beta which is indicative of high risk for such firms. The experimental results show that firms due to having more future investment hold high cash reserves.

Swanson and Alltizer (2010) examine the investment returns of created portfolios according to trading strategies, based on forecasting good news against bad news about the cash holdings level. The 2392 sample of firms are drawn from the population of U.S. companies in various industries during the period 1980 to 1999 . They show that firms which hold cash more than expected, have greater investment returns.

Plazzo (2012) examines the relationship between cash holdings, risk and expected returns in U.S. companies during the period 1975 to 2009 . He presents a model that emphasizes on how is the relationship between cash flows and risks arising from the company's cash holdings policies. In this model, firms with higher risk, have higher tendency to use costly external financing for their growth opportunities financing and instead have higher optimal cash reserve. The results also indicate a positive relationship between expected stock returns and cash holdings. In addition, this positive relationship for firms with fewer growth opportunities is stronger.

Anagnostopoulou (2012) studies the determinants of cash and their impact on future operating performance during the period 2001 to 2009 among 1,826 public companies and 2909236 private companies in the UK. The results of this research reveal that liquidity ratios of private companies are lower than public companies. As well as position of the companies on the stock exchange significantly affect cash holdings, even after controlling for the effect of financial constraints on corporate cash policy. Furthermore, this study

1High Cash Minus Low Cash 
shows that excess cash is positively associated with future operational performance of private companies, but this relationship does not exist in public companies.

Martinez Sola et al. (2013) examine the effects of cash on firm value for a sample of 475 U.S. companies during the period 2001 to 2007 . The results show that there is a significant relationship between the optimal level of cash and firm value; this confirms that there is an optimal level of cash for companies. Also the positive or negative deviation from the optimal cash level can decrease the value of the company.

Yahyazadehfar Far et al. (2013) contend that firms which hold more cash than optimal cash will have lower investment returns. They investigate the relationship between excess cash holdings and future performance in 188 active accepted firms of Tehran Stock Exchange (TSE) during 2002-2011. The results indicate that there is a negative and significant relationship between excess cash holdings and future performance.

\section{Hypotheses Development}

Jensen (1986) and Oler and Picconi (2007) suggest that future performance should be decreasing in excess cash because of overinvestment. Although the findings by Mikkelson and Partch (2003) contradict this expectation, we extend their work with a larger Iranian sample, and we also examine whether insufficient cash also affects future performance.

Keynes's (1936) transaction motive suggests that firms holding insufficient cash will underperform because they have additional costs in order to run their operations. These costs include higher interest rates from borrowers who likely view the cash strapped firm as more risky and administrative costs related to obtaining cash from external sources because it is not internally available. In addition, firms with insufficient cash have a reduced ability to take on new projects that would improve future performance. According to the research literature and in order to achieve the research objectives, two main hypotheses are presented which each of the different hypotheses regarding the possible outcomes for each of the positive deviations (excess cash) and negative deviations (insufficient cash) is divided into two parts:

H1: There is a positive relationship between excess cash and future cumulative abnormal returns.

H2: There is a negative relationship between insufficient cash and future cumulative abnormal returns.

\section{Methods}

\subsection{Optimal Level of Cash}

Optimal cash model is a criterion which shows optimal level of cash for each company with regard to the specific characteristics of that company. The results of this model will be used to measure the effects of deviations from optimal level of cash holdings on future performance. The dependent variable used in this model is obtained by extending Opler et al. (1999) model. The model used to determine the company optimal level of cash is as follows:

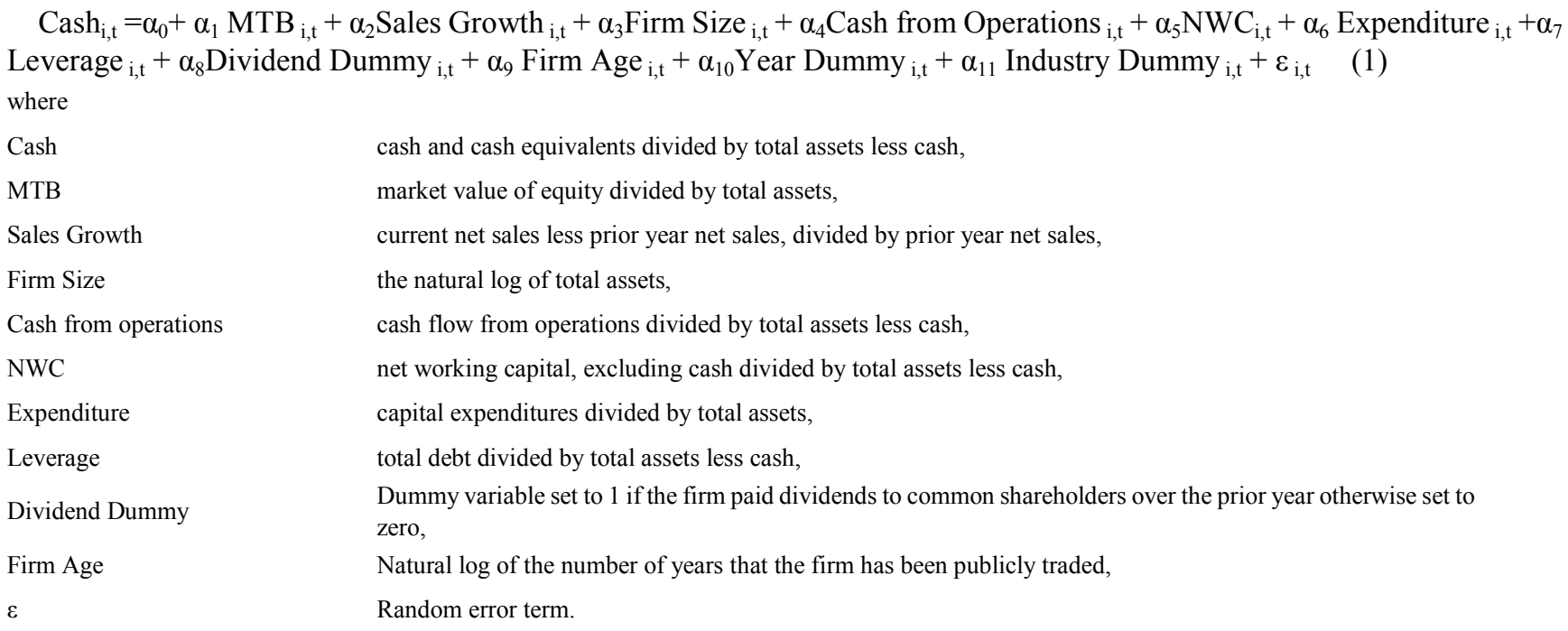

We use the estimation of optimal cash level to extract each firm's insufficient and excess cash level. To avoid a peek-ahead bias, we estimate optimal cash by estimating Equation (1) for the prior five years and obtaining estimated coefficients. We use these coefficients to estimate each firm's optimal cash level as of the end of the current year.2 This gives us estimated optimal cash levels for each firm-year, from 2002 to 2011.

2For example, to estimate optimal cash level for the year 2010 for a given firm, we use the estimated coefficients from our regression using data from 2005 to 2009 . For years before 2004 we use all available prior years, because our data is only available from 2002 onward. 


\subsection{Estimating the effect of cash level on future Return on Net Operating Assets}

In order to examine the first hypothesis, the return on net operating assets model (RNOA) is used. Excess and insufficient cash indicate the company deviation from optimal level of cash. In fact these two factors constitute the main independent variables in this study. It is expected that with increasing deviation from the optimal level of estimated cash, and consequently the increase in excess and insufficient cash variables, reduce the future return on operating assets. The second Equation is as follows:

RONA $_{\mathrm{i}, \mathrm{t}+1}=\alpha_{0}+\alpha_{1}$ Excess Cash $_{\mathrm{i}, \mathrm{t}}+\alpha_{2}$ Insufficient Cash $_{\mathrm{i}, \mathrm{t}}+\alpha_{3} \mathrm{NWC}_{\mathrm{i}, \mathrm{t}}+\alpha_{4}$ Sales Growth $_{\mathrm{i}, \mathrm{t}}+\alpha_{5}$ Leverage $_{\mathrm{i}, \mathrm{t}}+\alpha_{6}$ Firm Size $_{\mathrm{i}, \mathrm{t}}+$ $\alpha_{7}$ RONA $_{\mathrm{i}, \mathrm{t}}+\alpha_{8}$ Firm Age $_{\mathrm{i}, \mathrm{t}}+\alpha_{9}$ Firm Age $_{\mathrm{i}, \mathrm{t}}+\alpha_{10}$ Year Dummy $_{\mathrm{i}, \mathrm{t}}+\alpha_{11}$ Industry Dummy $_{\mathrm{i}, \mathrm{t}}+\varepsilon_{\mathrm{i}, \mathrm{t}}$ where

RONA

Operating income after depreciation divided by net operating assets as defined by Fairfield and Yohn, (2001) and Soliman, (2008).

Excess Cash

difference between cash and optimal cash, set to zero for the negative range, so that only positive values (and zero) remain,

Insufficient Cash

Difference between cash and optimal cash, set to zero for the positive range, and for the negative range the absolute value is used.

\subsection{Estimating the effect of cash level on future cumulative abnormal returns}

In this research cumulative abnormal returns are used to estimate future returns. As well as we include firm age in our estimation model; younger firms may have a particularly difficult time obtaining necessary liquidity, and may therefore be more susceptible to encountering difficulty if they run short of cash. It follows that younger firms may do significantly better than expected if they hold extra cash reserves. To accommodate this possibility, we add a young firm dummy to model. Also, uses control variables such as market-to-book (Fama and French 1993) and total accruals (Richardson et al., 2005).To examine the second hypothesis, the future accumulative abnormal return (CAR) model is used. Holding more or less cash than optimal cash is factor than can affect company's performance; future accumulative abnormal return is a criterion that used to measure shareholder's understanding from holding excess or sufficient cash and its effect on performance. It is expected that these deviations lead to abnormal return instead of the market return. The third Equation is as follows:

$\mathrm{CAR}_{\mathrm{i}, \mathrm{t}+1}=\alpha_{0}+\alpha_{1}$ Excess Cash $_{\mathrm{i}, \mathrm{t}}+\alpha_{2}$ Insufficient Cash $_{\mathrm{i}, \mathrm{t}}+\alpha_{3}$ Young firm Dummy $_{\mathrm{i}, \mathrm{t}}+\alpha_{4}$ Young firm Dummy * Insufficient

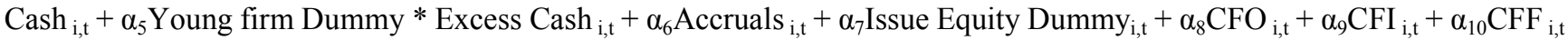
$+\alpha_{11}$ Year Dummy $_{\mathrm{i}, \mathrm{t}}+\alpha_{12}$ Industry Dummy $_{\mathrm{i}, \mathrm{t}}+\varepsilon_{\mathrm{i}, \mathrm{t}}$ where

CAR

This variable is defined following Beaver et al. (2007): calculate future returns as the size-adjusted cumulative abnormal returns from the beginning of month +4 relative to the firm's fiscal year end to 12 months later. 3 difference between cash and optimal cash, set to zero for the negative range, so that only positive values (and

Excess Cash zero) remain,

Insufficient Cash

Young firm Dummy

Accruals

Issue Equity Dummy

CFO

CFI

CFF
Difference between cash and optimal cash, set to zero for the positive range, and for the negative range the absolute value is used.

Dummy variable set to 1 if the firm is in the bottom quartile of firms ranked by age,

This variable is defined following Richards net al. (2005) as:

$\mathrm{TACC}=\Delta \mathrm{WC}+\Delta \mathrm{NCO}+\Delta \mathrm{FIN}$, where:

$\Delta=$ change from prior year to current year

$\mathrm{WC}=$ working capital $=$ current operating assets $(\mathrm{COA})$ less current operating liabilities $(\mathrm{COL})$

$\mathrm{COA}=$ current assets - cash and short-term investments

$\mathrm{COL}=$ current liabilities - debt in current liabilities

$\mathrm{NCO}=$ noncurrent operating assets $(\mathrm{NCOA})-$ noncurrent operating liabilities $(\mathrm{NCOL})$

$\mathrm{NCOA}=$ total assets - current assets - other investments and advances

$\mathrm{NCOL}=$ total liabilities - current liabilities - long-term debt

$\mathrm{FIN}=$ financial assets $(\mathrm{FA})-$ financial liabilities $(\mathrm{FL})$

$\mathrm{FA}=$ short-term investments + other investments and advances

$\mathrm{FL}=$ total liabilities + debt in current liabilities + preferred stock

Dummy variable set to 1 if the firm issued equity over the current year otherwise 0 ,

Cash flow from operations divided by total assets less cash,

Cet cash flow from investing divided by total assets less cash,

Net cash flow from financing divided by total assets less cash. 


\section{Data and Summary Statistics}

We select our sample of IRAN nonfinancial firms with available financial data from Tehran Stock Exchange (TSE) during 2003-2012. We exclude financial firms and firms which their financial data is not available. Observations with the main variables (Cash holding, Cash flow, Size, and Market to Book) ranking in the top or bottom 1\% are deleted. All other control variables are winsorized at the $1 \%$ level. Our final sample has 1880 firm-year observations.

Table 1. Descriptive Statistics

\begin{tabular}{|c|c|c|c|c|c|c|}
\hline & Mean & Median & Max & Min & Std dev & Obs \\
\hline \multicolumn{7}{|l|}{ Panel A: } \\
\hline CASH & 0.2613 & 0.0338 & 5.98862 & 0.03493 & 0.806476 & 1880 \\
\hline МТВ & 0.9397 & 0.6216 & 4.60714 & 0.03699 & 1.10395 & 1880 \\
\hline SALES GROWTH & 0.4670 & 0.1415 & 2.27272 & -3.4646 & 0.634554 & 1880 \\
\hline SIZE & 5.6599 & 5.6021 & 8.05402 & 4.09450 & 0.629419 & 1880 \\
\hline $\mathrm{CFO}$ & 0.1297 & 0.1243 & 3.60815 & -4.1112 & 1.618154 & 1880 \\
\hline NWC & -0.2211 & 0.0071 & 0.97696 & -4.2907 & 1.021034 & 1880 \\
\hline EXPENDITURE & -0.0682 & -0.0342 & 2.41888 & -0.1554 & 0.476349 & 1880 \\
\hline LEVERAGE & 0.7113 & 0.90992 & 9.01147 & 0.02321 & 1.00571 & 1880 \\
\hline DIVIDEND & 0.9244 & 1 & 1 & 0 & 1 & 1880 \\
\hline AGE & 0.9838 & 1.0413 & 3.05307 & 1 & 0.382505 & 1880 \\
\hline \multicolumn{7}{|l|}{ Panel B: } \\
\hline CAR & -0.36789 & -0.9286 & 2.66841 & 1.305211 & 0.03038 & 1880 \\
\hline EXCESSCASH & 0.07563 & -0.3488 & 0 & 0 & 0.23792 & 1880 \\
\hline INSUF CASH & 0.03046 & 0.34923 & 0.58327 & 0 & 0.13671 & 1880 \\
\hline YOUNGDUM & 0.25686 & 0.25456 & 1 & 0 & 0.43314 & 1880 \\
\hline YOUNGINF & 0.00535 & -0.1003 & 0 & -3.45225 & 0.66463 & 1880 \\
\hline YOUNGEXC & 0.00654 & 0.09055 & 4.58327 & 0 & 0.68137 & 1880 \\
\hline ACCRUAL & 0 & 0.23581 & 1 & 0 & 0.42463 & 1880 \\
\hline ISSUEDUM & 0.10137 & 0.07565 & 4.32156 & 0.845141 & 0.25648 & 1880 \\
\hline $\mathrm{CFO}$ & 0.16325 & 0.12056 & 0.64321 & -0.20654 & 0.18232 & 1880 \\
\hline CFI & -0.12654 & -0.3464 & 2.65483 & -0.97811 & 0.13866 & 1880 \\
\hline $\mathrm{CFF}$ & 0.09817 & 0.05654 & 4.32156 & -0.84514 & 0.25648 & 1880 \\
\hline
\end{tabular}

This table provides summary statistics for the variables in our sample of firm-years from Iran-based publicly traded firms over the period 2002 to 2011.CASH $H_{\mathrm{t}}$ is cash and cash equivalents divided by total assets less cash, $M T B_{t}$ is market value of equity divided by total assets, Sales Growth ${ }_{t}$ is current net sales less prior year net sales, divided by prior year net sales, Firm Size $_{t}$ is the natural log of total assets, Cash from operations $s_{t}$ is cash flow from operations divided by total assets less cash, $N W C_{t}$ is net working capital, excluding cash divided by total assets less cash, Expenditure $\mathrm{t}_{\mathrm{t}}$ is capital expenditures divided by total assets, Leverage $_{\mathrm{t}}$ is total debt divided by total assets less cash, Dividend Dummy $y_{t}$ is a dummy variable set to 1 if the firm paid dividends to common shareholders over the prior year otherwise set to zero and Firm Age $e_{t}$ is Natural log of the number of years that the firm has been publicly traded. $R O N A_{t}$ is Operating income after depreciation divided by net operating assets, Excess Cash $_{t}$ is difference between cash and optimal cash, set to zero for the negative range, so that only positive values (and zero) remain and Insufficient $\mathrm{Cash}_{t}$ is difference between cash and optimal cash, set to zero for the positive range, and for the negative range the absolute value is used. $C A R_{t}$ is future returns as the size-adjusted cumulative abnormal returns from the beginning of month +4 relative to the firm's fiscal year end to 12 months later, Young firm Dummy is a dummy variable set to 1 if the firm is in the bottom quartile of firms ranked by age, Accruals $s_{t}$ is total accruals, Issue Equity Dummy is a dummy variable set to 1 if the firm issued equity over the current year otherwise $0, C F O_{t}$ is cash flow from operations divided by total assets less cash, $C F I_{t}$ is net cash flow from investing divided by total assets less cash and $C F F_{t}$ is Net cash flow from financing divided by total assets less cash. All continuous variables are winsorized at top and bottom $1 \%$ level. 


\section{Empirical Results}

\subsection{Optimal level of cash holdings model estimation}

The first presented model in this research is optimal level of cash that is assumed, companies with their specific characteristics such as growth in sale, dividend payment and amount of cash flow, need to have a specific level of cash that is called optimal cash. It is expected that any positive or negative deviation from estimated optimal cash has negative effect on future performance and return. The real cash deviations of company from this optimal level of cash are used as independent variables in next models to examine the hypotheses. To control the problem of autocorrelation and heteroskedasticity of variance when we use panel data, use the generalized least squares method in Period Seemingly Unrelated Regressions (PSUR) framework.

Table 2. Optimal Level of Cash Holdings

\begin{tabular}{|c|c|c|c|c|c|c|}
\hline \multicolumn{7}{|c|}{ Dependent= Cash Holdings } \\
\hline & \multicolumn{3}{|c|}{ EGLS } & \multicolumn{3}{|c|}{ Least Squares } \\
\hline & Coef. & t-value & P-value & Coef. & t-value & P-value \\
\hline \multicolumn{7}{|l|}{ Panel A } \\
\hline MTB & 0.014616 & 3.521489 & 0.0004 & 0.027671 & 2.444304 & 2.444304 \\
\hline SALES GROWTH & 0.001257 & 2.511325 & 0.0121 & 0.000776 & 0.465373 & 0.6417 \\
\hline SIZE & 0.000230 & 0.008867 & 0.9929 & -0.016082 & -0.777904 & 0.4367 \\
\hline $\mathrm{CFO}$ & -0.142483 & -7.775917 & 0.0000 & 0.333453 & 11.26239 & 0.0000 \\
\hline NWC & -1.106701 & -134.0713 & 0.0000 & -0.252754 & -4.428421 & 0.0000 \\
\hline CAPEX & 0.486931 & 7.809894 & 0.0000 & -1.120519 & -11.14410 & 0.0000 \\
\hline LEVERAGE & 0.000793 & 0.193099 & 0.8469 & 0.918602 & 15.27387 & 0.0000 \\
\hline DIVIDEND & 0.020601 & 0.925009 & 0.3551 & 0.176582 & 3.513602 & 0.0005 \\
\hline AGE & 0.217461 & 6.558955 & 0.0000 & 0.000687 & 0.019530 & 0.9844 \\
\hline $\mathrm{C}$ & -0.211428 & -1.578797 & 0.1146 & -0.752240 & -5.203206 & 0.0000 \\
\hline $\mathrm{R}^{2}$ & 0.973805 & - & - & 0.816881 & - & - \\
\hline$\overline{\mathrm{R}^{2}}$ & 0.970744 & - & - & 0.815998 & - & - \\
\hline D.W & 1.610080 & - & - & 1.504170 & - & - \\
\hline F. Statistic & 318.0597 & - & 0.0000 & 924.4063 & - & 0.0000 \\
\hline
\end{tabular}

Market-to-Book has positive significant effect on optimal level of cash. This is due to the need for more cash in companies faced with more growth opportunities. There is a positive and significant relationship between sales growth and optimal level of cash which is a confirmation on provided explanation on positive and significant relationship between Market-to-Book and optimal level of cash. There is no significant evidence about the relationship between firm size and optimal level of cash. As well as the results show that there is a negative and significant relationship between cash from operation and optimal level of cash. This result is probably due to low liquidity circulation and entry small volume of liquidity on the Tehran Stock Exchange companies. Net working capital has negative and significant relationship with optimal level of cash. Probably because there is less liquidity circulation in companies that have more net working capital. Obtained coefficient for capital expenditure shows that has a positive and significant relationship with optimal level of cash. The results show that companies with regard to their need for cash (capital expenditure is representative), hold more cash. There are no significant evidence for leverage and dividend about the relationship with optimal level of cash. Firm age has positive and significant relationship with optimal level of cash. Usually, most companies have a longer life, report a lot of debt in their balance sheets. So maybe these companies are facing difficulties in additional financing from outside the company. Obtained coefficient for $R^{2}$ is $97 \%$ which shows the independent variables have a high explanatory power of dependent variable. $D . W$ statistic is 1.61 , which is nearly two and indicates the absence of autocorrelation in the model. $F$ statistics which presented in table 2 reveals that, the model is significant in confidence level of $99 \%$. 


\subsection{Future cumulative abnormal return model estimation}

Cumulative abnormal returns are representative of future returns which is a criterion to assess the predictive power of investors. In this section with estimating the relationship between excess and insufficient cash and future cumulative abnormal returns, examine the second hypothesis.

Table 3. Cumulative Abnormal Returns estimation results

\begin{tabular}{|c|c|c|c|c|c|c|}
\hline \multicolumn{7}{|c|}{ Dependent $=$ CAR } \\
\hline & \multicolumn{2}{|c|}{ EGLS } & \multicolumn{4}{|c|}{ GMM } \\
\hline & Coef. & t-value & P-value & Coef. & t-value & P-value \\
\hline \multicolumn{7}{|l|}{ Panel C } \\
\hline EXCESS CASH & -0.013280 & -1.858984 & 0.0300 & -0.223581 & -0.221671 & 0.0824 \\
\hline INSUF CASH & -0.018134 & -2.002583 & 0.0538 & -0.487720 & -1.473451 & 0.0140 \\
\hline YOUNGDUM & -0.287103 & -4.014534 & 0.0000 & -2.362653 & -0.468587 & 0.0647 \\
\hline YOUNGINF & 0.082591 & 3.131195 & 0.0085 & 3.632768 & 0.518790 & 0.0639 \\
\hline YOUNGEXC & -0.192569 & -2.955272 & 0.0000 & 1.622902 & 0.457318 & 0.0604 \\
\hline ACCRUAL & $-3.01 \mathrm{E}-08$ & -0.785667 & 0.4907 & $-1.72 \mathrm{E}-06$ & -0.649092 & 0.5164 \\
\hline ISSUEDUM & 0.029981 & 1.117880 & 0.3190 & 0.245739 & 0.297455 & 0.7662 \\
\hline $\mathrm{CFO}$ & $2.10 \mathrm{E}-08$ & 0.281947 & 0.6192 & $4.86 \mathrm{E}-06$ & 0.952382 & 0.3411 \\
\hline CFI & 4.43E-08 & 2.588774 & 0.0261 & $9.23 \mathrm{E}-06$ & 1.070362 & 0.0284 \\
\hline $\mathrm{CFF}$ & $6.41 \mathrm{E}-08$ & 2.074277 & 0.0577 & $2.57 \mathrm{E}-06$ & 0.491175 & 0.0623 \\
\hline CAR(-1) & - & - & & -0.064418 & -3.614163 & 0.0003 \\
\hline Year Dummy & $\sqrt{ }$ & & & $\sqrt{ }$ & & \\
\hline Industry Dummy & $\sqrt{ }$ & & & $\sqrt{ }$ & & \\
\hline CONSTANT & -0.844448 & -34.28218 & 0.0000 & - & - & - \\
\hline Adjusted R-squared & 0.65 & 0.62 & & 0.74 & 0.72 & - \\
\hline D.W & 2.137253 & - & & - & - & - \\
\hline F. Statistic & 2.970353 & - & 0.0000 & - & - & - \\
\hline
\end{tabular}

The results show that there is a negative and significant relationship between excess cash and future cumulative abnormal return. Companies with excess cash holdings lose investment opportunities which will lead to lower future returns. If excess cash increases one unite, leads to 0.013 unit decrease in future cumulative abnormal return. This results show that the market does not understand completely the effect of excess cash in current year. The insufficient cash has a negative relationship. Due to lack of liquidity, major losses comes to company, in other words, face with increasing in cost of external financing and liquidity risks which has negative effect on future performance which ultimately reduces company future returns (future cumulative abnormal returns). If insufficient cash increases one unite, leads to 0.018 unit decrease in future cumulative abnormal return. Young firm dummy negatively related to dependent variable.

The greater age, is much more familiar with the capital markets and easier access to them which can lead to better use of investment opportunities and ultimately greater returns than younger firms. Insufficient cash in young firms has negative relationship with future cumulative abnormal returns. Contrary to expectation, Young firms due to investing in investment opportunities, to gain greater returns and faster growth hold less cash than optimal level of cash. As well as excess cash has negative effect on dependent variable that is a confirmation for findings about insufficient cash in young firms. There are no significant evidences about the relationship between Accruals and Issue Equity Dummy. Also, there is no relationship between cash flow from operations and future cumulative abnormal returns, as it can be seen as a reflection in current returns. Cash flow from investing and cash flow from financing have positive effects. Obtained coefficient for $R^{2}$ is 0.28 and D.W statistic is 2.1, which indicates the absence of autocorrelation in the model. $F$ statistics which presented in table 3 reveals that, the model is significant in confidence level of $99 \%$. Overall, the results from this model confirm both parts of the second hypothesis and shows when a firm has less or more cash than optimal level of cash the future performance decreases. They can increase the value of their shares through adjusting their cash level to optimal level of cash.

\section{Conclusions}

In this research, we examine the hypotheses regarding the existence of a significant negative relationship between deviation from optimal level of cash holdings and future 
performance in Tehran Stock Exchange (TSE) companies. To determine the amount of excess and insufficient cash of firms, the optimal level of cash model is used. Obtained results of the first model shows that as Opler et al. (1999) and Simutin (2010) findings, Market- to-Book has a positive and significant effect on optimal level of cash holdings which is contradicts with Oler and Picconi (2010).Sale growth positively related to optimal level of cash which is consistent with the findings of Oler and Picconi (2010). Contrary to expectation, firm size has no significant effect on optimal level of cash which is contradicts with Opler et al. (1999), Simutin (2010) and Oler and Picconi (2010) findings. Unlike Opler et al. (1999), the findings of this research indicate that there is a negative relationship between cash flow from operations and optimal level of cash holdings which is in line with Oler and Picconi (2010) findings. Net working capital negatively related with optimal level of cash holdings which is consistent with Simutin (2010) and is contradicts with Opler et al. (1999) and Oler and Picconi (2010) findings. Like Opler et al. (1999) and Oler and Picconi (2010), obtained coefficient for capital expenditure shows the positive relation with optimal level of cash holdings which is contradicts with Simutin (2010). There is no significant evidence between the relationship between leverage and optimal level of cash which is contradicts with Opler et al. (1999) that find negative and significant relationship between them. As well as the coefficient of dividend shows that has no effect on optimal level of cash holdings which is contradicts with Oler and Picconi (2010) that finds positive and significant relationship between them. Firm age positively related to optimal level of cash which is consistent with Oler and Picconi (2010).

After calculating excess and insufficient cash variables using optimal cash model, we examine the future performance using the second model. Hypotheses tests results using the second model show indicate that as expected, excess and insufficient cash has negative significant relationships with future cumulative abnormal returns which is in line with Oler and Picconi (2010) and is contradicts with Kevin (2007) findings. These results show that, companies which hold more or less cash than optimal level of cash can increase the value of their shares through adjusting their cash level to optimal level of cash.

In general, it is inferred that there is a negative significant relationship between deviation from optimal level of cash and futureperformance. This findings is contradicts with Simutin (2010) and Swanson and Alltizer (2010) which find, holding more cash lead to greater stock return and finally better performance. As well as is contradicts with Palazzo (2009) which finds no significant between cash holdings level and stock returns. But these results are consistent with Oler and Picconi (2010) findings which find negative and significant relationship between deviation from optimal level of cash holdings and performance.

\section{REFERENCES}

[1] Anagnostopoulou, Seraina C., 2012. Cash Holdings: Determinants and Impact on Future Operating Performance for Listed vs. Unlisted Firms. Available at: http://papers.ssrn.com/sol3/papers.cfm?abstract_id=2028605

[2] Beaver, W., McNichols, M., Price, R., 2007. Delisting Returns and Their Effect on Accounting-Based Market Anomalies. Journal of Accounting and Economics 43, 341-368.

[3] Desai, H., Rajgopal, S., Venkatachalam, M., 2004. Value-Glamour and Accruals Mispricing: One Anomaly or Two? The Accounting Review. 79, 355-385.

[4] Dittmar, A., Mahrt-Smith, J., Servaes, H., 2007.Corporate governance and the value of cash holdings. Journal of Financial Economics 83, 599-634.

[5] Fairfield, M. P. and Yohn, T.L., 2001. Using asset turnover and profit margin to forecast changes in profitability. Review of accounting studies $6,371-385$.

[6] Fama, E. F., French, K. R., 1993. Common Risk Factors in the Returns on Stocks and Bonds. Journal of Financial Economics33, 3-56.

[7] Harford, Jarrad; Mansi, Sattar A., and William F. Maxwell, 2008. Corporate Governance and Firm Cash Holdings, Journal of Financial Economics 87, 535-555.

[8] Jensen، M., 1986. Agency Costs of Free Cash Flow, Corporate Finance and Takeover. American Economic Review. 76، 323-9.

[9] Kevin K. Li, 2007. Expected Holding of Cash, Future Performance and Stock Return. Available at: http://papers.ssrn.com/sol3/papers.cfm?abstract_id=1214962

[10] Keynes, J. M. (1936). «The General Theory of Employment, Interest and Money». Harcourt Brace, London.

[11] Loughran, T., Ritter, J. R. (1995). The New Issues Puzzle. Journal of Finance. 50, 23-51.

[12] Martinez-Sola, C., García-Teruel, P. J. and Martínez-Solano, P., 2013. Corporate cash holding and firm value, Applied Economics 45 (2), 161-170.

[13] Mikkelson, W. H., Partch, M. M., 2003. Do Persistent Large Cash Reserves Hinder Performance? Journal of Quantitative Finance 38, 275-294.

[14] Oler, D., Picconi, M., 2007. Implications of Suboptimal Cash Holdings for Future Performance. Working paper, Kelley School of Business, Indiana University.

[15] Oler, D., Picconi, M., 2010. Implications of insufficient and excess cash for future performance. Working paper. Indiana University. Available at: http://papers.ssrn.com/sol3/papers.cfm?abstract_id=1092880

[16] Opler T., Pinkowitz L., Stulz R., Williamson R., 1999. The Determinants and Implications of Corporate Cash Holdings, Journal of Financial Economics 52, 3-46.

[17] Palazzo, D., 2009. Firm's Cash Holdings and the Cross-Section of Equity Returns. Boston University Working Paper. 
[18] Plazzo, B., 2012. Cash holdings, risk and expected returns, Journal of Financial Economics 104, 162-185.

[19] Richardson, S. A., Sloan, R. G., 2003. External Financing, Capital Investment, and Stock Returns. Working paper, University of Pennsylvania.

[20] Richardson, S. A., Sloan, R. G., Soliman, M. T., Tuna, I., 2005. Accrual Reliability, Earnings Persistence and Stock Prices. Journal of Accounting and Economics 39, 437-485.

[21] Simutin, M., 2010. Excess Cash and Stock Returns. Journal of Financial Management, 39(3), 1197-1222.

[22] Soliman.T. M., 2008. The use of dupont analysis by market participants. The accounting Review, 83(3), 823-853.

[23] Sun, Q, Yung, K., Rahman, H., 2012. Earnings quality and corporate cash holdings, Journal of Accounting and Finance $52,543-571$.

[24] Swanson, Z. L., 2006. Impact of Cash holdings on Investment Value. Working paper. Kelley School of Business, Indiana University.

[25] Swanson, Z. L. and Richard L. Alltizer, 2010. Cash Position Forecasts and Stock Market Portfolio Returns. Available at: http://papers.ssrn.com/sol3/papers.cfm?abstract_id=1618990

[26] U.S Treasury, 2002. Cash management made Easy. Department of the Treasury Financial Management Service.

[27] Yahyazadehfar Far, M., Yadollahzadeh Tabari, N.A., Akbari, M.A., 2013. Excess Cash holdings and Cumulative Abnormal Returns. World of Sciences Journal 8, 181-191. 